\title{
Multidimensional evaluation of the elderly undergoing cardiac surgery*
}

\author{
Avaliação multidimensional de idosos submetidos à cirurgia cardíaca \\ Evaluación multidimensional de ancianos sometidos a cirugía cardíaca
}

\author{
Marinez Kellermann Armendaris ${ }^{1}$, Pedro Sadi Monteiro ${ }^{2}$
}

\begin{abstract}
Objective: Know the multidimensional aspects of the elderly undergoing cardiac surgery. Methods: Descriptive epidemiological study conducted in the Cardiology Institute of the Distrito Federal-IC/DF. The instrument used for data collection contained the following variables: sociodemographic, clinical, assessment scores of cognitive function, emotional and functional capacity. Chi-square and Student's T tests were used for data analysis. Results: Among the total population, 64\% was female; illiterate elderly and with minimal training, combined, accounted for $80 \%$. Dyslipidemia and systolic hypertension were the most prevalent chronic diseases. More than $50 \%$ of the elderly presented cognitive and emotional amendments, and functional dependency to some extent. Conclusion: These results point to the complexity of the elderly regarding their health condition, and also refer to the need for an integrated approach in health that reflects on improvements in the quality of life of the elderly.
\end{abstract}

Keywords: Multidimensional assessment; Thoracic surgery; Aged

\section{RESUMO}

Objetivo: Conhecer aspectos multidimensionais do idoso submetido à cirurgia cardíaca. Métodos: Estudo epidemiológico descritivo, realizado no Instituto de Cardiologia do Distrito Federal-IC/DF. Utilizou-se para a coleta de dados instrumento contendo as variáveis: sócio demográficas, clínicas, scores de avaliação da função cognitiva,capacidade funcional e emocional. Testes do Qui-quadrado e T de Student foram empregados para a análise dos dados. Resultados: Da população total, 64\% era do sexo feminino; Idosos não alfabetizados e com formação mínima, somados, representavam 80\%.Dislipidemia, e Hipertensão arterial sistólica, foram às doenças crônicas mais prevalentes. Mais de $50 \%$ dos idosos apresentaram alterações cognitivas e afetivas, e algum grau de dependência funcional. Conclusão: Esses resultados apontam para a complexidade do idoso no que se refere á sua condição de saúde, bem como, remete a necessidade de uma abordagem integral em saúde que reflita em melhora de sua qualidade de vida.

Descritores: Avaliação multidimensional; Cirurgia cardíaca; Idoso

\section{RESUMEN}

Objetivo: Conocer aspectos multidimensionales Del anciano sometido a cirugía cardiaca. Métodos: Se trata de um estudio epidemiológico descriptivo, realizado en el Instituto de Cardiología del Distrito Federal-IC/DF. Para la recolección de los datos se utilizó un instrumento que contenía las variables: sociodemográficas, clínicas, escores de evaluación de la función cognitiva, capacidad funcional y emocional. Para el análisis de los datos se emplearon los tests del Chi-cuadrado y T de Student. Resultados: De la población total, el 64\% era del sexo femenino; Ancianos analfabetos y con formación mínima que, sumados, representaban el 80\%.Dislipidemia, e Hipertensión arterial sistólica, fueron las enfermedades crónicas más prevalentes. Más del 50\% de los ancianos presentaron alteraciones cognitivas y afectivas, y algún grado de dependencia funcional. Conclusión: Esos resultados apuntan hacia la complejidad del anciano respecto a su condición de salud, así como también, remite a la necesidad de un abordaje integral en salud que refleje en mejora de su calidad de vida.

Descriptores: Evaluación multidimensional; Cirugía Torácica; Anciano

\footnotetext{
* Work performed at the University of Brasilia and the Institute of Cardiology - Brasilia (DF), Brazil.

${ }^{1}$ Graduate (MSc) in Nursing, Graduate Program in Nursing, University of Brasilia - UnB - Brasilia (DF), Brazil.

${ }^{2}$ Postdoctoral Researcher, University College of London. Associate Professor, Department of Nursing, University of Brasilia - UnB - Brasilia (DF), Brazil.
} 


\section{INTRODUCTION}

The progressive increase in life expectancy of the population has motivated the realization of an exponential series of scientific papers in the field of attention to the health of the elderly ${ }^{(1)}$. It is expected that in $2025,14 \%$ of the population in the country will be aged over 60 years ${ }^{(2)}$. Associated with changes in the age characteristics of the population, there is also a change in the epidemiological profile of the diseases in the country, with an increased incidence of Non-Communicable Chronic Diseases - NCCDs (Doenças Crônicas Não-Transmissíveis - DCNTs) ${ }^{(1,3)}$.

Studies ${ }^{(2,3)}$ have shown that the NCCDs have significant influence on the functional capacity of the elderly, data that reveal a predominance of cardiovascular disease (CVDs) in this population. In this context the high prevalence of systolic hypertension ( $\mathrm{SAH})$ stands out, what may increase the chance of the elderly to present any degree of dependency when performing Instrumental Activities of Daily Living (IADL) in up to $39 \%$. In the presence of coronary artery disease (CAD), more significant alterations are perceived and may increase this dependency by up to $82 \%$.

With the aging process, physical, psychological and social changes are expected and in this sense authors ${ }^{(4-6)}$ propose to the elderly a multidimensional assessment, perceiving this individual as a biological, psychological, social, emotional and rational being. The Guideline of Cardiogeriatics $\mathrm{II}^{(5)}$ emphasizes that in care with the health of the elderly, it is necessary that the involved professionals respect the due particularities in the process of aging. The decrease in pain sensitivity and the memory and hearing impairment may result in lower accuracy of the information collected from the patient and lead to misdiagnosis ${ }^{(5,6)}$.

Aging produces a reduction of the self-care ability, which reflects a higher or lower degree of patient dependency. It represents a situation that generates changes in the care routine. resulting in stress of the caregiver/ family, in need to adapt the environment and in frailty of the patient. Data ${ }^{(6)}$ show that $5 \%$ of the people aged over 65 years lose the ability to perform simple care related to the Basic Activities of Daily Living (BADL) such as taking a shower, and this rate increases to $30 \%$ when the age is over 85 years.

Thus this study is justified by an integrated assessment of the current health of the elderly, especially the one who will undergo a procedure of high complexity such as cardiac surgery. The information obtained through a multidimensional approach may allow the healthcare team to establish a differential diagnosis and detect possible self-care deficits that, if observed precociously, can minimize sequelae, improve the quality of assistance and grant to the family and the society the reintroduction of a functionally and cognitively capable elderly, that is socially adapted to the aging process $^{(1,6)}$. Given the above, this study aimed to understand the multidimensional capacity of the elderly in the pre and postoperative periods of the cardiac surgery.

\section{METHODS}

This is a descriptive study based on the epidemiol$\operatorname{ogy}^{(7)}$, methodology that allowed researchers to understand the distribution and variation of frequencies of the selected events, focused on this specific population.

The study was conducted in the Cardiology Institute of the Distrito Federal/DF, reference institution in cardiology in the Midwest of Brazil. To compose the sample were included the elderly classified as so in accordance with the Statute of the Elderly ${ }^{(8)}$, aged 60 years and over; of both genders; with a medical diagnosis of coronary artery disease, major valve or valvular heart disease; indication for elective cardiac surgery; who underwent a median-sternal thoracotomy surgical approach, and that after the invitation, agreed to participate of the research and signed a Term of Consent (Termo de Consentimento Livre e Esclarecido - TCLE). Were excluded of the sample the patients aged $<60$ years; patients older than 60 years who, at the time of interview showed important neurological-cognitive amendments such as verbal and hearing impairment and that, as a result of the abnormalities, presented difficulties in answering the standardized questionnaire, once the data collection was performed directly by obtaining self-reported responses; elderly aged 60 years who underwent emergency cardiac surgery; an those who did not agree to participate of the study.

The patients were selected from a convenience sample. The size of the sample was estimated taking into account the literature data that show an incidence of $21.6 \%$ of patients undergoing cardiovascular operations ${ }^{(9)}$. A confidence interval of $95 \%$ was defined, with a margin of error of $3 \%$; thus reaching the number of 20 patients to be examined, and to these were added five more individuals, in order to prevent possible losses.

The data were collected through a semi-structured type of questionnaire. The variables examined in this study were classified as: sociodemographic, clinical (identified by physical examination), mental (classification scores of cognitive function), functional (scores rating the degree of dependency of the elderly to perform Basic and Instrumental Activities of Daily Living), emotional (identification of depressive symptoms). For analysis of the clinical variables equipments (sphygmomanometers, stethoscopes and scales) were used, calibrated and certified, and the scores were es- 
tablished as follows: Body Mass Index ${ }^{(10)}(\mathrm{BMI})\left(\mathrm{kg} / \mathrm{m}^{2}\right)$, $=18$ (underweight), 18.5 to 24.9 (normal), 25.0 to 29.9 (overweight), = 30 (obese); Blood pressure (BP) millimeters of mercury, $<120<80$ (optimum), $<130<85$ (normal), 130-139 85-89 (borderline), 140-159 90-99 (stage 1 hypertension stage 1), 160-179 100-109 (stage 2 hypertension); Respiratory rate (RR) of an adult at rest, normal values between 14 and 20 breaths per minute; Heart rate of an adult at rest, normal values between 60 and 100 beats per minute ${ }^{(5)}$.

Rating scales: To assess the cognitive function, the Mini Mental State Examination (MMSE) was used, it is a tool used worldwide, developed in 1974, translated and adapted to Portuguese in $1994^{(6)}$. It influences the scores when associated with the variables age and education ${ }^{(6)}$, its maximum score is 30 points, in this study scores $=$ 23 were considered as abnormal. In the assessment of functional capacity it was used the version validated and adapted into Portuguese ${ }^{(11)}$ of the BrazilianVersionMultimensionalFunctionalAssesmentQuestionaire (BOMFAQ), specifically the section 5, which describes the functionality of the elderly when performing BADL and IADL. The following scores were set: $(0)$ for independent, (1 to 3) light dependency, (4 to 6) moderate dependency and (7 or + ) severe dependency. For the collection of possible depressive symptoms, it was adopted the Geriatric Depression Scale of Yesavage (GDS-15), which is one of the most widely used instruments for screening depression symptoms in the population classified as elderly. The scale is a simplified version of the original, validated into a Brazilian version in $1999^{(12)}$, scores $=5$ were considered abnormal. The application of the tool aiming the data collection was completed in two different moments as follows: preoperative - at the hospital, in the first contact with the patient; in this opportunity the researchers were introduced and the objectives of the study exposed; following this, the patients were invited to participate of the research and those who agreed were invited to sign the Term of Consent. After this the instruments for data collection were applied, including sociodemographic information, physical examination upon admission and application of assessment cognitive, functional and emotional scales. During hospitalization the clinical evolution of the patient was followed and additional information was included with observations on the medical chart; postoperatively home visits were conducted, with prior scheduling by telephone. At this stage the established postoperative period of 90 days was respected, considering the minimum time of convalescence and evolution of the inflammatory process caused by surgical injury ${ }^{(13)}$. The data collection was carried out from October/2011 to February/2012. The conduction of the study was in accordance with the criterion of Resolution $n^{\circ}$ 196/96 of the National Health Council, and the project of research was approved by the Ethics Committee in Research of the Institution where it was developed (Protocol nº: 078/2011- CEP/ICDF).

\section{RESULTS}

The 25 elderly included in the study were treated in the Unified Health System (Sistema Único de Saúde SUS), and referred through institutional agreements, from the health units of the Distrito federal (GDF) to the institution participating of the research. The minimum time for performing the postoperative assessment was 90 days from the discharge date, with an average of 120 days between evaluations.

As for sociodemographic characterization, the majority of the elderly included in the study $(92 \%)$ resides in the Distrito Federal (DF). The average age was 67.88 years $(\mathrm{sd}= \pm 5.50)$. In this sample, patients of the female gender represented the greatest proportion $(64 \%)$. The white ethnicity was significantly $(\mathrm{p}=0.05)$ higher among the respondents, representing $84 \%$ of the total. The status of widowhood appears in $24 \%$ of the elderly of the female gender, and the prevalent marital status was married (64\%), a statistically significant value $(p=0.05)$ among categories.

Of older respondents, $56 \%$ have families composed of more than three children and in the same proportion, $56 \%$ live with their spouses or any other blood related member, such as sons, daughters, brothers or sisters. A higher percentage of the elderly $(80 \%)$, regardless the gender, although retired, engage in some kind of productive activity, whether at home or performing some service as self-employed. Regarding the educational level of the interviewed elderly, $32 \%$ are illiterate and moreover, $48 \%$ have minimal training. The predominant family income in the sample was one minimum wage, in $52 \%$ of the sample.

Regarding the morbidities, the Myocardial Revascularization Surgery (CABG) was responsible for the major part of the procedures performed $(80 \%)$, followed by cardiovascular disease (CVD) associated (coronary heart disease and valvular heart disease) - responsible for $12 \%$ of the surgeries. The medical diagnosis of at least one Non-Communicable Chronic Disease (NCCD) was present in all elderly patients included in the study (100\%). The Dyslipidemia (DLP) appears in $84 \%$ of the cases; followed by Hypertension, with $76 \%$ of the cases; endocrine-metabolic diseases (type I and II diabetes and thyroid diseases) summed appear in more than half of the patients $(64 \%)$. It is also noteworthy the presence of neurological diseases, those of the urinary system and oncologic diseases, with rates of $16 \%, 12 \%$ and $8 \%$, respectively (Table 1 ). 
Table 1. Distribution of the main clinical variables; scores of assessment of the cognitive function, of the functional and emotional capacity of the elderly who underwent cardiac surgery, Institute of Cardiology/DF, Brasília, October/2011 to February/2012

Period of study

\begin{tabular}{|c|c|c|c|c|}
\hline Variables & Preoperative & $(\%)$ & Postoperative & $(\%)$ \\
\hline \multicolumn{5}{|c|}{ Body mass index $(\mathrm{kg} / \mathrm{m} 2)$} \\
\hline Mean $( \pm$ sd $)$ & $27.14( \pm 5.00)$ & & $27.68( \pm 4.6)$ & \\
\hline Underweight & 1 & 4.0 & & 0 \\
\hline Normal & 6 & 24.0 & & 4 \\
\hline Overweight & 15 & 60.0 & & 14 \\
\hline Obese & 3 & 12.0 & & 4 \\
\hline \multicolumn{5}{|c|}{ Blood pressure (BP) (mmHg) } \\
\hline Systolic Mean ( \pm dp) & $120.20( \pm 14.32)$ & & $141.72( \pm 20.74)$ & \\
\hline Diastolic Mean ( \pm dp) & $64.76( \pm 14.87)$ & & $74.27( \pm 15.23)$ & \\
\hline Optimum & 16 & 64.0 & 3 & 13.6 \\
\hline Normal & 2 & 8.0 & 5 & 22.7 \\
\hline Borderline & 4 & 16.0 & 1 & 4.54 \\
\hline Stage 1 hyipertension & 3 & 12.0 & 11 & 50 \\
\hline Stage 2 hypertension & 0 & 0.0 & 2 & 9.1 \\
\hline
\end{tabular}

\section{Respiratory rate (mrpm)}
Mean $( \pm \mathrm{sd})$
$18.52( \pm 1.38)$

Normal at rest

Heart rate (bpm)

$$
\text { Mean ( } \pm \text { sd) }
$$

Normal at rest

\section{Typical Chest Pain}

$$
\text { Yes }
$$$$
\text { No }
$$

Cognitive state

Normal (>27)

Questionable (24-26)

Amended $(<23)$

Functional capacity

Independent (0)

Light dependency (1-3)

Moderate dependency (4-6)

Severe dependency $(7$ or + )
25

$66.36( \pm 7.83)$

25

100.0

28.0

72.0

18

9

5

11

$\begin{array}{ll}9 & 36.0 \\ 7 & 28.0 \\ 4 & 16.0 \\ 5 & 20.0\end{array}$

$19.86( \pm 0.77)$

$$
22
$$

100.0

$64.90( \pm 9.75)$

$$
22
$$

100.0

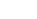

0.0

18.2

0.54

9.1

90.9

0.00

45.4

13.6

40.9

0.00

40.9

18.2

27.3

13.6

\section{Emotional state}

$$
\text { Normal }(\leq 5)
$$

Amended $(\geq 5)$

$\begin{array}{cc}23 & 92.0 \\ 2 & 8.0\end{array}$

92.0
8.0

* P values derived from the Student's T and Chi-square tests. Source: The authors. 
It is observed that during the preoperative the BMI of the study's population on its majority $(60 \%)$ was classified as overweight, increasing significantly ( $\mathrm{p}=$ $0.00)$ to $63.6 \%$ in the postoperative. As for the average blood pressure (BP), the result found shows a statistically significant increase $(p=0.00)$, in consideration of the values related to systolic and diastolic blood pressures, when comparing the pre and postoperative periods; it is noted that $64 \%$ of the patients in the preoperative period were classified with great pressure levels and postoperatively in $50 \%$ of the cases the elderly were classified as stage 1 hypertensive.

Considering possible changes in the cognitive status, when adding the scores classified as amended+questionable, the results point that more than half of the sample $(64 \%)$ has presented some sort of loss of the cognitive function during the preoperative period, while in the postoperative the proportion was of $54.5 \%$, revealing a significant improvement $(p=0,00)$. The functional capacity impaired, regardless of the operative period, was observed in more than half of the studied population, $64 \%$ in the preoperative and $59.1 \%$ in the postoperative. Possible depressive symptoms were identified in $8 \%$ of the patients in the preoperative and in $4.5 \%$ of the patients in the postoperative.

\section{DISCUSSION}

As for the age group, the study showed that more than half $(64 \%)$ of the respondents were aged less than 70 years. These results are similar to other findings that show a higher proportion of young patients who underwent cardiac surgery, a factor that may be related to the disease progression or to an early diagnosis. The progress of age ${ }^{(5)}$ represents a risk factor for the symptomatic evolution of the cardiovascular disease, affecting around $76 \%$ of the people in the age group "70 years and over". The female gender was predominant in the composition of the sample, which can be explained by the fact that cardiovascular mortality is higher and earlier in men $^{(5)}$, as expected in relation to the current demographic composition of elderly (higher probability of survival among women $)^{(14)}$. A Brazilian study in Juiz de Fora / MG, in the 1999-2001 period already showed this trend; of all the 9710 deaths of city residents, among people aged 35-64, 61.2\% were males and a higher proportion of deaths $(39 \%)$ was from ischemic heart disease ${ }^{(15)}$.

In the family context it was found that more than half of the respondents (84\%) lived with some blood related member and this fact is due to the increased longevity of its members, making it possible to have a longer coexistence with an intergenerational family ${ }^{(16)}$. From this perspective it is possible to observe that for the elderly who have any kind of functionality loss, the familiar environment is extremely important, once the exposure to a surgical procedure leads to the necessity of a caregiver, role normally attributed to a family member.

The development of some work activity was reported by the majority $(80 \%)$ of the patients. This factor is directly related to the functional capacity and the need for another income to add to the retirement benefit, once the income prevalent in this population was one minimum wage. This data reflects another important social indicator which is the low level or no education of the elderly patients. This result corroborates with the findings of the World Health Organization ${ }^{(17)}$, in which stands out the fact that the majority of older people in all countries still represent a vital resource for the families and communities, whether in formal or informal work.

In this study, Coronary Artery Disease (CAD) was responsible for $80 \%$ of the surgical procedures performed, data that resemble other findings, which show the high prevalence of this pathology and its relevance in the list of chronic diseases, being the most common cause of morbidity and mortality in developed and developing countries worldwide ${ }^{(18)}$.

The present study revealed that all the respondents had a medical diagnosis of at least one chronic disease associated with the basic pathology, and the Dyslipidemia (DLP) and Hypertension ( $\mathrm{SAH}$ ) were the most prevalent. The Non-Communicable Chronic Diseases (NCCD) accompany the aging of the population and directly affect the functional capacity of the elderly, causing loss of autonomy and increased demands on health ${ }^{(3)}$. It stands out in this study the difficulty of the elderly patient to maintain the values BP/BMI within normality during the postoperative period. These difficulties may be related to low education, poor access to health services and little knowledge of patients/relatives about the cardiovascular risk factors.

Authors ${ }^{(15)}$ reinforce this possibility and relate this problem to the poor socioeconomic conditions in which most of the population lives, a factor that produces effects on accessibility to information about health, healthy eating and physical activity practice, as well as the use of assistive technology in health.

Associated with the presence of a chronic disease and with the limited socioeconomic conditions, in this study was observed a high level of dependency for the performance of BADLs and IADLs by the investigated patients, as well as an amended cognitive state in most of the cases. Similar results were described in a research ${ }^{(3)}$ conducted in São Paulo, which identified the presence of $\mathrm{SAH}$ in $53.4 \%$ of the respondents and showed the statistically significant association between 
cardiac diseases and reduction of the functional capacity of the elderly patient.

In this study it was found that the amended cognitive state, as well as some degree of dependency present in more than half of the population, suggest a condition of vulnerability of this individual, especially on the verge of a treatment of high complexity that leads one to experience physiological changes resultant of the surgical procedure itself, as well as the inadequate development of the necessary self-care during recovery ${ }^{(6)}$.

Recent studies have shown the relationship between cardiovascular disease as a risk factor for the development of vascular dementia. The changes caused by the disease may be minimal or even larger including the Alzheimer's type $^{(19)}$ A research ${ }^{(20)}$ conducted in 2004 that measured the impact of hospitalization in the functional capacity of the elderly showed an association between low functional capacity, cognitive deficit and the presence of acute delirium, suggesting the need for further observation of this population during the hospitalization period. In face with this context it is necessary to develop clinic and environmental specific interventions, with a multidisciplinary approach that favors the treatment and a preparation for the hospital discharge ${ }^{(2,6)}$.

We also highlight the presence of depressive symptoms in $8 \%$ of the population studied. Studies conducted in Brazil refer to a prevalence of depression among the elderly of between $5 \%$ and $35 \%$, when considered the different forms and severity. These abnormalities currently represent a public health problem and often go unnoticed ${ }^{(3,18)}$.

It is understood as a limitation of this study the focus on a more general assessment of the health condition of the studied population. The applied methodology sought to analyze the variables, without the intention of knowing possible associations between alleged causes and their respective effects, yet it is necessary that the issues addressed here are to be deepened with analytical studies.

\section{CONCLUSION}

Given the multidimensional aspects that involve health at an old age, it can be concluded in this study that the majority of the elderly patients who underwent cardiac surgery were female. Coronary artery disease was the most common disease in the indication of surgery and SAH was the most prevalent morbidity in this population. There was a high proportion (40\%) of seniors who had scores suggestive of cognitive impairment; in the assessment of functional capacity, more than half of the elderly had some degree of dependency; $8 \%$ of the elderly patients who underwent cardiac surgery showed suggestive scores of amended emotional state. These results point to the complexity of the elderly with regard to their health condition and refer to the need for an integrated approach in health that reflects on improvement in their quality of life.

\section{REFERENCES}

1. Fonseca FB, Rizzotto ML. [Instrument construction for sócio-functional evaluation in elderly people]. Texto \& Contexto Enferm. 2008;17(2): 365-73. Portuguese.

2. Rodrigues RA, Scudeller PG, Pedrazzi EC, Schiavetto FV, Lange C. Morbidity and interference in seniors' functional ability. Acta Paul Enferm. 2008; 21(4):643-8.

3. Alves LC, Leimann BC, Vasconcelos ME, Carvalho MS, Vasconcelos AG, Fonseca TC, et al. [The effect of chronic diseases on functional status of the elderly living in the city of São Paulo, Brazil]. Cad Saúde Pública. 2007; 23(8): 192430. Portuguese.

4. Morin E. Os sete saberes necessário à educação do futuro. 2a ed. [Internet]. Silva CE, Sawaya J, tradutores. Brasília: Cortez; 2000 [citado 2012 Out 30]. Disponível em: http:// www.juliotorres.ws/textos/textosdiversos/SeteSaberesEdgarMorin.pdf

5. II Diretrizes em Cardiogeriatria da Sociedade Brasileira de Cardiologia. Arq Bras Cardiol .2010 95 Suppl 2: 1-112.

6. Netto MP. Tratado de gerontologia. 2a ed. São Paulo: Atheneu. 2007.

7. Pereira MG. Epidemiologia: teoria e prática. Rio de Janeiro: Guanabara Koogan; 2008.

8. Alves Júnior L, Rodrigues AJ, Évora PR, Basseto S, Scorzoni Filho A, Luciano PM, et al. [Risk factors in septuagenarians or elderly patients undergone coronary artery bypass grafting and or valves operations]. Rev Bras Cir Cardiovasc.
2008;23(4): 550-5. Portuguese.

9. Brasil. Ministério da Saúde. Lei n. 10741 , de $1^{\circ}$ de outubro de 2003. Dispõe sobre o Estatuto do Idoso e dá outras providências [Internet]. Diário Oficial da República Federativa do Brasil, Brasília(DF); 2003 Out 3 [citado 2012 Out 31]. Disponível em: http://www.planalto.gov.br/ ccivil_03/leis/2003/L10.741.htm

10. World Health Organization (WHO). Obesity: preventing and managing the global epidemic. Report of a WHO consultation. Genebra: WHO; 2000. [ Technical Report Series, n. 894].

11. Ramos, LR, Rosa TEC, Oliveira ZM, Medina MCG, Santos FRG. Perfil do idoso em área metropolitana na região sudeste do Brasil: resultados de inquérito domiciliar. Rev Saúde Pública.1993;27(2):87-94.

12. Almeida OP; Almeida SA. [Reliability of the Brazilian version of the geriatric depression scale (GDS) short form]. Arq Neuropsiquiatr.1999; 57(2B):421-6.

13. Flores AM, Zohman LR. Reabilitação do paciente cardíaco. In: Delisa JA. Gans MB; Tratado de medicina de reabilitação: princípios e práticas. 3a ed. São Paulo: Editora Manole. 2002. Vol. 2, cap.54. p. 1408-9.

14. Santos AA, Pavarini SC. Functionality of elderly people with cognitive impairments in different contexts of social vulnerability. Acta Paul Enferm. 2011;24(4):520-6.

15. Nogueira MC, Ribeiro C, Cruz OG. [Social inequalities in premature cardiovascular mortality in a medium-size Brazilian 
city].Cad. Saúde Pub. 2009;25(11):2321-32. Portuguese.

16. Santos AA, Pavarini SC, Brito TR. [Profile of elderly people with cognitive alterations in different contexts of social vulnerability]. Esc Anna Nery. 2010;14(3):496-504. .

17. World Health Organization. Envelhecimento ativo: uma política de saúde. Tradução Suzana Gontijo. Brasília: OPAS; 2005.

18. Farias N, Souza JM, Laurente R, Alencar SM. Cardiovascular mortality by gender and age range in the city of São Paulo,
Brazil: 1996 to 1998, and 2003 to 2005. Arq Bras Cardiol. 2009;93(5):498-505.

19. Maineri NL, Xavier FM, Berleze MC, Moriguchi EH. [Risk factors for cerebrovascular disease and cognitive function in the elderly]. Arq Bras Cardiol. 2007; 89(3): 168-62. Portuguese.

20. Siqueira AB, Cordeiro RC, Perracini MR, Ramos LR. [Functional impact of hospitalization among elderly patients]. Rev Saúde Pública. 2004; 38(5): 687-94. Portuguese. 